\title{
Evaluation of Biostimulants Added to Post Emergence Herbicides in Soybean
}

\author{
Nader Soltani*, Christy Shropshire, Peter H. Sikkema \\ University of Guelph, Ridgetown Campus, Ridgetown, Canada \\ Email: *soltanin@uoguelph.ca
}

How to cite this paper: Soltani, N., Shropshire, C. and Sikkema, P.H. (2016) Evaluation of Biostimulants Added to Post Emergence Herbicides in Soybean. American Journal of Plant Sciences, 7, 1729-1740. http://dx.doi.org/10.4236/ajps.2016.713162

Received: August 4, 2016

Accepted: September 13, 2016

Published: September 16, 2016

Copyright $\odot 2016$ by authors and Scientific Research Publishing Inc. This work is licensed under the Creative Commons Attribution International License (CC BY 4.0).

http://creativecommons.org/licenses/by/4.0/ (c) (i) Open Access

\begin{abstract}
There is little information on the effect of the addition of biostimulants such as AX1304-4, Crop Booster or RR Soy Booster to post emergence herbicides in soybean under Ontario environmental conditions. A total of 69 field experiments were conducted in soybean at two locations (Ridgetown and Exeter, Ontario, Canada) to evaluate the effect of biostimulants added to various post emergence herbicides on crop injury, weed control and yield of soybean. There was minimal soybean injury ( $6 \%$ or less) from glyphosate, chlorimuron, imazethapyr, fomesafen or quizalofop applied alone or in combination with biostimulants. At 4 weeks after herbicide treatment (WAT), the addition of biostimulants to glyphosate, chlorimuron, imazethapyr, fomesafen or quizalofop did not affect weed control except for control of common ragweed which was increased $2 \%$ with the addition of RR Soy Booster to glyphosate + imazethapr, and the control of common lambs quarters which was increased $4 \%$ with the addition of Crop Booster to glyphosate + fomesafen. At 8 WAT, biostimulants evaluated had no effect on weed control except for Crop Booster added to glyphosate + fomesafen which increased green foxtail control $2 \%$ and Crop Booster added to glyphosate + chlorimuron, glyphosate + fomesafen and glyphosate + quizalofop which increased common lambs quarters control $1 \%, 3 \%$, and $4 \%$, respectively. The addition of biostimulants to the post emergence herbicides evaluated had no effect on soybean yield. Based on these results, the addition of biostimulants such as AX13-04-4, Crop Booster or RR Soy Booster to commonly used post emergence herbicides in Ontario has no significant effect on crop injury, weed control or yield of soybean.
\end{abstract}

\section{Keywords}

Herbicide, Injury, Soybean, Tolerance, Weeds, Yield 


\section{Introduction}

Soybean Glycine max (L.) Merr is important to the agricultural economy in Canada where nearly 5,100,000 tonnes of soybean are produced on approximately 1,700,000 ha with an approximate farm gate value of $\$ 1,000,000,000$ [1] [2]. Globally, Canada ranked 7 th in the world with $2 \%$ of soybean production in 2012-2013 [1]. Ontario soybean growers need to implement optimal agronomic practices, including proper weed management and plant nutrition, to maximize their production efficiency.

Various biostimulants have been available for a number of years [3]-[8]. Biostimulants have been defined as compounds, substances and other products such as microorganisms, trace elements, enzymes, plant growth regulators that when applied in small quantities to plants or soils can enhance plant growth and development by increasing the efficiency of physiological process within plants [3] [4]. Some studies have reported that biostimulants enhance nutrient availability, increase water-holding capacity, increase antioxidants, enhance metabolism and increase chlorophyll production in plants [4]-[11].

AX13-04-4, Crop Booster and RR Soy Booster are three biostimulants developed by Axter Agro sciences Inc. (895, Chemin Benoit, Mont-St-Hilaire, Quebec, J3G 4S6, Canada) for use in various crops to increase seed yield through enhancement of crop vigor and foliage development [12]-[14]. These biostimulants contain approximately $15 \%$ total nitrogen, $3 \%$ phosphoric acid $\left(\mathrm{P}_{2} \mathrm{O}_{5}\right), 6 \%$ soluble potash $\left(\mathrm{K}_{2} \mathrm{O}\right), 0.02 \%$ boron, $0.05 \%$ chelated manganese, $0.05 \%$ molybdenum, $0.05 \%$ chelated zinc, and $0.5 \%$ E.D.T.A. (chelating agent) [13] [14].

According to the Axter Agro sciences Inc., AX13-04-4, Crop Booster, and RR Soy Booster have the ability to compensate for plant's inability to take up sufficient nutrients under stressed conditions and decrease herbicide induced stress that may be caused by post emergence herbicides [12].

The effects of these biostimulants, added to commonly used post emergence herbicides, in soybean production in Ontario are not known. Ontario growers need scientific data on effect of these biostimulants to make informed decisions on their use in their production system. In absence of such data, growers rely on their "best guess" when using these products which may result in application of ineffective products that reduce net return and cause unnecessary loading of chemicals into the environment.

The objective of this study was to evaluate the effect of adding a biostimulant to glyphosate, glyphosate + chlorimuron, glyphosate + imazethapyr, glyphosate + fomesafen and glyphosate + quizalofop applied post emergence on crop injury, weed control and soybean yield under Ontario environmental conditions.

\section{Materials and Methods}

A total of 69 field experiments were conducted in soybean at the Huron Research Station, Exeter, Ontario and University of Guelph Ridgetown Campus, Ridgetown, Ontario. All field trials were established as a randomized complete block design with four replications. Herbicide and biostimulant treatments are listed in Tables 1-9. 
Table 1. Comparison of weed control 4 and 8 WAT, and yield for glyphosate alone vs glyphosate + Crop Booster in Roundup Ready soybean ${ }^{\mathrm{a}}$.

\begin{tabular}{|c|c|c|c|c|}
\hline \multirow{2}{*}{ Weed } & \multirow{2}{*}{ Treatment } & \multirow{2}{*}{ Rate $\left(\mathrm{ha}^{-1}\right)$} & \multicolumn{2}{|c|}{ Control (\%) } \\
\hline & & & 4 WAT & 8 WAT \\
\hline \multirow[t]{2}{*}{ AMASS } & Glyphosate & $900 \mathrm{~g}$ ae & 94 & 93 \\
\hline & Glyphosate + Crop Booster & $900 \mathrm{~g}$ ae $+2 \mathrm{~L}$ & 94 & 93 \\
\hline \multirow[t]{2}{*}{ AMBEL } & Glyphosate & $900 \mathrm{~g}$ ae & 95 & 95 \\
\hline & Glyphosate + Crop Booster & $900 \mathrm{~g}$ ae $+2 \mathrm{~L}$ & 95 & 96 \\
\hline \multirow[t]{2}{*}{ CHEAL } & Glyphosate & $900 \mathrm{~g}$ ae & 95 & 95 \\
\hline & Glyphosate + Crop Booster & $900 \mathrm{~g}$ ae $+2 \mathrm{~L}$ & 96 & 96 \\
\hline \multirow[t]{2}{*}{ SETVI } & Glyphosate & $900 \mathrm{~g}$ ae & 98 & 98 \\
\hline & Glyphosate + Crop Booster & $900 \mathrm{~g}$ ae $+2 \mathrm{~L}$ & 98 & 98 \\
\hline \multirow[t]{3}{*}{ SINAR } & Glyphosate & $900 \mathrm{~g}$ ae & 86 & 97 \\
\hline & Glyphosate + Crop Booster & $900 \mathrm{~g}$ ae $+2 \mathrm{~L}$ & 80 & 96 \\
\hline & & & MT $\cdot \mathrm{ha}^{-1}$ & \\
\hline \multirow[t]{3}{*}{ Yield } & Weedy control & & 2.04 & \\
\hline & Glyphosate & $900 \mathrm{~g}$ ae & 3.06 & \\
\hline & Glyphosate + Crop Booster & $900 \mathrm{~g}$ ae $+2 \mathrm{~L}$ & 3.12 & \\
\hline
\end{tabular}

Abbreviations: AMASS, green or redroot pigweed; AMBEL, common ragweed; CHEAL, common lambs quarters; SETVI, green foxtail; SINAR, wild mustard; WAT, weeks after herbicide application. Significance of contrasts comparing glyphosate alone with glyphosate + Crop Booster denoted by ${ }^{*}$ for $\mathrm{P}<0.10$ and ${ }^{\star *}$ for $\mathrm{P}<0.05$ beside the means.

Table 2. Comparison of weed control 4 and 8 WAT, and yield for glyphosate alone vs glyphosate + Soy Booster in Roundup Ready soybean ${ }^{\mathrm{a}}$.

\begin{tabular}{|c|c|c|c|c|}
\hline \multirow{2}{*}{ Weed } & \multirow{2}{*}{ Treatment } & \multirow{2}{*}{ Rate $\left(\right.$ ha $\left.^{-1}\right)$} & \multicolumn{2}{|c|}{ Control (\%) } \\
\hline & & & $4 \mathrm{WAT}$ & $8 \mathrm{WAT}$ \\
\hline \multirow[t]{2}{*}{ AMASS } & Glyphosate & $900 \mathrm{~g}$ ae & 93 & 91 \\
\hline & Glyphosate + Soy Booster & $900 \mathrm{~g} \mathrm{ae}+2 \mathrm{~L}$ & 92 & 93 \\
\hline \multirow[t]{2}{*}{ AMBEL } & Glyphosate & $900 \mathrm{~g}$ ae & 94 & 95 \\
\hline & Glyphosate + Soy Booster & $900 \mathrm{~g}$ ae $+2 \mathrm{~L}$ & 96 & 96 \\
\hline \multirow[t]{2}{*}{ CHEAL } & Glyphosate & $900 \mathrm{~g}$ ae & 99 & 98 \\
\hline & Glyphosate + Soy Booster & $900 \mathrm{~g} \mathrm{ae}+2 \mathrm{~L}$ & 98 & 96 \\
\hline \multirow[t]{2}{*}{ SETVI } & Glyphosate & $900 \mathrm{~g}$ ae & 99 & 98 \\
\hline & Glyphosate + Soy Booster & $900 \mathrm{~g}$ ae $+2 \mathrm{~L}$ & 99 & 98 \\
\hline \multirow[t]{3}{*}{ SOLPT } & Glyphosate & $900 \mathrm{~g}$ ae & 81 & 80 \\
\hline & Glyphosate + Soy Booster & $900 \mathrm{~g} \mathrm{ae}+2 \mathrm{~L}$ & 81 & 79 \\
\hline & & & MT.ha ${ }^{-1}$ & \\
\hline \multirow[t]{3}{*}{ Yield } & Weedy control & & 1.13 & \\
\hline & Glyphosate & $900 \mathrm{~g}$ ae & 2.44 & \\
\hline & Glyphosate + Soy Booster & $900 \mathrm{~g}$ ae $+2 \mathrm{~L}$ & 2.51 & \\
\hline
\end{tabular}

Abbreviations: AMASS, green or redroot pigweed; AMBEL, common ragweed; CHEAL, common lambs quarters; SETVI, green foxtail; SOLPT, Eastern black nightshade; WAT, weeks after herbicide application. Significance of contrasts comparing glyphosate alone with glyphosate + Soy Booster denoted by ${ }^{*}$ for $\mathrm{P}<0.10$ and ${ }^{* *}$ for $\mathrm{P}<0.05$ beside the means. 
Table 3. Comparison of weed control 4 and 8 WAT, and yield for glyphosate + chlorimuron alone vs glyphosate + chlorimuron + AX13-04-4 in Roundup Ready soybean ${ }^{\text {a }}$.

\begin{tabular}{|c|c|c|c|c|}
\hline \multirow{2}{*}{ Weed } & \multirow{2}{*}{ Treatment } & \multirow{2}{*}{ Rate $\left(\mathrm{ha}^{-1}\right)$} & \multicolumn{2}{|c|}{ Control (\%) } \\
\hline & & & $4 \mathrm{WAT}$ & $8 \mathrm{WAT}$ \\
\hline \multirow[t]{2}{*}{ AMASS } & Glyphosate + chlorimuron & $900 \mathrm{~g}$ ae $+9 \mathrm{~g}$ ai & 97 & 99 \\
\hline & Glyphosate + chlorimuron + AX13-04-4 & $900 \mathrm{~g}$ ae $+9 \mathrm{~g}$ ai $+2 \mathrm{~L}$ & 100 & 100 \\
\hline \multirow[t]{2}{*}{ AMBEL } & Glyphosate + chlorimuron & $900 \mathrm{~g}$ ae $+9 \mathrm{~g}$ ai & 96 & 98 \\
\hline & Glyphosate + chlorimuron + AX13-04-4 & $900 \mathrm{~g}$ ae $+9 \mathrm{~g}$ ai $+2 \mathrm{~L}$ & 97 & 98 \\
\hline \multirow[t]{2}{*}{ CHEAL } & Glyphosate + chlorimuron & $900 \mathrm{~g}$ ae $+9 \mathrm{~g}$ ai & 98 & 98 \\
\hline & Glyphosate + chlorimuron + AX13-04-4 & $900 \mathrm{~g}$ ae $+9 \mathrm{~g}$ ai $+2 \mathrm{~L}$ & 97 & 99 \\
\hline \multirow[t]{3}{*}{ SETVI } & Glyphosate + chlorimuron & $900 \mathrm{~g}$ ae $+9 \mathrm{~g}$ ai & 98 & 99 \\
\hline & Glyphosate + chlorimuron + AX13-04-4 & $900 \mathrm{~g}$ ae $+9 \mathrm{~g}$ ai $+2 \mathrm{~L}$ & 98 & 98 \\
\hline & & & MT $\cdot \mathrm{ha}^{-1}$ & \\
\hline \multirow[t]{3}{*}{ Yield } & Weedy control & & 2.73 & \\
\hline & Glyphosate + chlorimuron & $900 \mathrm{~g}$ ae $+9 \mathrm{~g}$ ai & 3.61 & \\
\hline & Glyphosate + chlorimuron + AX13-04-4 & $900 \mathrm{~g}$ ae $+9 \mathrm{~g}$ ai $+2 \mathrm{~L}$ & 3.68 & \\
\hline
\end{tabular}

Abbreviations: AMASS, green or redroot pigweed; AMBEL, common ragweed; CHEAL, common lambsquarters; SETVI, green foxtail; WAT, weeks after herbicide application. Significance of contrasts comparing glyphosate + chlorimuron alone with glyphosate + chlorimuron + AX13-04-4 denoted by ${ }^{*}$ for $\mathrm{P}<0.10$ and ${ }^{* *}$ for $\mathrm{P}<0.05$ beside the means.

Table 4. Comparison of weed control 4 and 8 WAT, and yield for glyphosate + chlorimuron alone vs glyphosate + chlorimuron + Crop Booster in Roundup Ready soybean ${ }^{\mathrm{a}}$.

\begin{tabular}{|c|c|c|c|c|}
\hline \multirow{2}{*}{ Weed } & \multirow{2}{*}{ Treatment } & \multirow{2}{*}{ Rate $\left(\mathrm{ha}^{-1}\right)$} & \multicolumn{2}{|c|}{ Control (\%) } \\
\hline & & & 4 WAT & 8 WAT \\
\hline \multirow[t]{2}{*}{ AMASS } & Glyphosate + chlorimuron & $900 \mathrm{~g}$ ae $+9 \mathrm{~g}$ ai & 99 & 100 \\
\hline & Glyphosate + chlorimuron + Crop Booster & $900 \mathrm{~g}$ ae $+9 \mathrm{~g}$ ai $+2 \mathrm{~L}$ & 99 & 99 \\
\hline \multirow[t]{2}{*}{ AMBEL } & Glyphosate + chlorimuron & $900 \mathrm{~g}$ ae $+9 \mathrm{~g}$ ai & 94 & 97 \\
\hline & Glyphosate + chlorimuron + Crop Booster & $900 \mathrm{~g}$ ae $+9 \mathrm{~g}$ ai $+2 \mathrm{~L}$ & 93 & 97 \\
\hline \multirow[t]{2}{*}{ CHEAL } & Glyphosate + chlorimuron & $900 \mathrm{~g}$ ae $+9 \mathrm{~g}$ ai & 98 & 98 \\
\hline & Glyphosate + chlorimuron + Crop Booster & $900 \mathrm{~g}$ ae $+9 \mathrm{~g}$ ai $+2 \mathrm{~L}$ & 98 & 99 \\
\hline \multirow[t]{2}{*}{ SETVI } & Glyphosate + chlorimuron & $900 \mathrm{~g}$ ae $+9 \mathrm{~g}$ ai & 99 & 99 \\
\hline & Glyphosate + chlorimuron + Crop Booster & $900 \mathrm{~g}$ ae $+9 \mathrm{~g}$ ai $+2 \mathrm{~L}$ & 99 & 99 \\
\hline \multirow[t]{3}{*}{ SINAR } & Glyphosate + chlorimuron & $900 \mathrm{~g}$ ae $+9 \mathrm{~g}$ ai & 97 & 100 \\
\hline & Glyphosate + chlorimuron + Crop Booster & $900 \mathrm{~g}$ ae $+9 \mathrm{~g}$ ai $+2 \mathrm{~L}$ & 97 & 100 \\
\hline & & & MT.ha ${ }^{-1}$ & \\
\hline \multirow[t]{3}{*}{ Yield } & Weedy control & & 2.47 & \\
\hline & Glyphosate + chlorimuron & $900 \mathrm{~g}$ ae $+9 \mathrm{~g}$ ai & 3.51 & \\
\hline & Glyphosate + chlorimuron + Crop Booster & $900 \mathrm{~g}$ ae $+9 \mathrm{~g}$ ai $+2 \mathrm{~L}$ & 3.52 & \\
\hline
\end{tabular}

Abbreviations: AMASS, green or redroot pigweed; AMBEL, common ragweed; CHEAL, common lambsquarters; SETVI, green foxtail; SINAR, wild mustard; WAT, weeks after herbicide application. Significance of contrasts comparing glyphosate + chlorimuron alone with glyphosate + chlorimuron + Crop Booster denoted by ${ }^{*}$ for $\mathrm{P}<0.10$ and ** for $\mathrm{P}<0.05$ beside the means. 
Table 5. Comparison of weed control 4 and 8 WAT, and yield for glyphosate + chlorimuron alone vs glyphosate + chlorimuron + Soy Booster in Roundup Ready soybean ${ }^{\mathrm{a}}$.

\begin{tabular}{|c|c|c|c|c|}
\hline \multirow{2}{*}{ Weed } & \multirow{2}{*}{ Treatment } & \multirow{2}{*}{ Rate $\left(\mathrm{ha}^{-1}\right)$} & \multicolumn{2}{|c|}{ Control (\%) } \\
\hline & & & $4 \mathrm{WAT}$ & 8 WAT \\
\hline \multirow[t]{2}{*}{ ABUTH } & Glyphosate + chlorimuron & $900 \mathrm{~g}$ ae $+9 \mathrm{~g}$ ai & 83 & 87 \\
\hline & Glyphosate + chlorimuron + Soy Booster & $900 \mathrm{~g}$ ae $+9 \mathrm{~g}$ ai $+2 \mathrm{~L}$ & 85 & 88 \\
\hline \multirow[t]{2}{*}{ AMASS } & Glyphosate + chlorimuron & $900 \mathrm{~g}$ ae $+9 \mathrm{~g}$ ai & 100 & 99 \\
\hline & Glyphosate + chlorimuron + Soy Booster & $900 \mathrm{~g}$ ae $+9 \mathrm{~g}$ ai $+2 \mathrm{~L}$ & 99 & 99 \\
\hline \multirow[t]{2}{*}{ AMBEL } & Glyphosate + chlorimuron & $900 \mathrm{~g}$ ae $+9 \mathrm{~g}$ ai & 93 & 92 \\
\hline & Glyphosate + chlorimuron + Soy Booster & $900 \mathrm{~g}$ ae $+9 \mathrm{~g}$ ai $+2 \mathrm{~L}$ & 92 & 91 \\
\hline \multirow[t]{2}{*}{ CHEAL } & Glyphosate + chlorimuron & $900 \mathrm{~g}$ ae $+9 \mathrm{~g}$ ai & 99 & 99 \\
\hline & Glyphosate + chlorimuron + Soy Booster & $900 \mathrm{~g}$ ae $+9 \mathrm{~g}$ ai $+2 \mathrm{~L}$ & 99 & 99 \\
\hline \multirow[t]{3}{*}{ SETVI } & Glyphosate + chlorimuron & $900 \mathrm{~g}$ ae $+9 \mathrm{~g}$ ai & 100 & 100 \\
\hline & Glyphosate + chlorimuron + Soy Booster & $900 \mathrm{~g}$ ae $+9 \mathrm{~g}$ ai $+2 \mathrm{~L}$ & 100 & 100 \\
\hline & & & MT.ha ${ }^{-1}$ & \\
\hline \multirow[t]{3}{*}{ Yield } & Weedy control & & 2.51 & \\
\hline & Glyphosate + chlorimuron & $900 \mathrm{~g}$ ae $+9 \mathrm{~g}$ ai & 3.40 & \\
\hline & Glyphosate + chlorimuron + Soy Booster & $900 \mathrm{~g}$ ae $+9 \mathrm{~g}$ ai $+2 \mathrm{~L}$ & 3.47 & \\
\hline
\end{tabular}

Abbreviations: ABUTH, velvetleaf; AMASS, green or redroot pigweed; AMBEL, common ragweed; CHEAL, common lambsquarters; SETVI, green foxtail; WAT, weeks after herbicide application. Significance of contrasts comparing glyphosate + chlorimuron alone with glyphosate + chlorimuron + Soy Booster denoted by ${ }^{*}$ for $\mathrm{P}<0.10$ and ${ }^{* *}$ for $\mathrm{P}<0.05$ beside the means.

Table 6. Comparison of weed control 4 and 8 WAT, and yield for glyphosate + imazethapyr alone vs glyphosate + imazethapyr + Crop Booster in Roundup Ready soybean ${ }^{\mathrm{a}}$.

\begin{tabular}{|c|c|c|c|c|}
\hline \multirow{2}{*}{ Weed } & \multirow{2}{*}{ Treatment } & \multirow{2}{*}{ Rate $\left(\mathrm{ha}^{-1}\right)$} & \multicolumn{2}{|c|}{ Control (\%) } \\
\hline & & & 4 WAT & 8 WAT \\
\hline \multirow[t]{2}{*}{ AMASS } & Glyphosate + imazethapyr & $900 \mathrm{~g}$ ae $+45 \mathrm{~g}$ ai & 98 & 99 \\
\hline & Glyphosate + imazethapyr + Crop Booster & $900 \mathrm{~g}$ ae $+45 \mathrm{~g}$ ai $+2 \mathrm{~L}$ & 99 & 99 \\
\hline \multirow[t]{2}{*}{ AMBEL } & Glyphosate + imazethapyr & $900 \mathrm{~g}$ ae $+45 \mathrm{~g}$ ai & 97 & 96 \\
\hline & Glyphosate + imazethapyr + Crop Booster & $900 \mathrm{~g}$ ae $+45 \mathrm{~g}$ ai $+2 \mathrm{~L}$ & 96 & 96 \\
\hline \multirow{2}{*}{ CHEAL } & Glyphosate + imazethapyr & $900 \mathrm{~g}$ ae $+45 \mathrm{~g}$ ai & 98 & 98 \\
\hline & Glyphosate + imazethapyr + Crop Booster & $900 \mathrm{~g}$ ae $+45 \mathrm{~g}$ ai $+2 \mathrm{~L}$ & 98 & 98 \\
\hline \multirow[t]{3}{*}{ SETVI } & Glyphosate + imazethapyr & $900 \mathrm{~g}$ ae $+45 \mathrm{~g}$ ai & 100 & 100 \\
\hline & Glyphosate + imazethapyr + Crop Booster & $900 \mathrm{~g}$ ae $+45 \mathrm{~g}$ ai $+2 \mathrm{~L}$ & 100 & 100 \\
\hline & & & MT.ha ${ }^{-1}$ & \\
\hline \multirow[t]{3}{*}{ Yield } & Weedy control & & 2.58 & \\
\hline & Glyphosate + imazethapyr & $900 \mathrm{~g}$ ae $+45 \mathrm{~g}$ ai & 3.46 & \\
\hline & Glyphosate + imazethapyr + Crop Booster & $900 \mathrm{~g}$ ae $+45 \mathrm{~g}$ ai $+2 \mathrm{~L}$ & 3.42 & \\
\hline
\end{tabular}

Abbreviations: AMASS, green or redroot pigweed; AMBEL, common ragweed; CHEAL, common lambsquarters; SETVI, green foxtail; WAT, weeks after herbicide application. Significance of contrasts comparing glyphosate $+\mathrm{im}-$ azethapyr alone with glyphosate + imazethapyr + Crop Booster denoted by ${ }^{*}$ for $\mathrm{P}<0.10$ and ${ }^{*}$ for $\mathrm{P}<0.05$ beside the means. 
Table 7. Comparison of weed control 4 and 8 WAT, and yield for glyphosate + imazethapyr alone vs glyphosate + imazethapyr + Soy Booster in Roundup Ready soybean ${ }^{\mathrm{a}}$.

\begin{tabular}{|c|c|c|c|c|}
\hline \multirow{2}{*}{ Weed } & \multirow{2}{*}{ Treatment } & \multirow{2}{*}{ Rate $\left(\right.$ ha $\left.^{-1}\right)$} & \multicolumn{2}{|c|}{ Control (\%) } \\
\hline & & & 4 WAT & $8 \mathrm{WAT}$ \\
\hline \multirow[t]{2}{*}{ ABUTH } & Glyphosate + imazethapyr & $900 \mathrm{~g}$ ae $+45 \mathrm{~g}$ ai & 88 & 85 \\
\hline & Glyphosate + imazethapyr + Soy Booster & $900 \mathrm{~g}$ ae $+45 \mathrm{~g}$ ai $+2 \mathrm{~L}$ & 87 & 85 \\
\hline \multirow[t]{2}{*}{ AMASS } & Glyphosate + imazethapyr & $900 \mathrm{~g}$ ae $+45 \mathrm{~g}$ ai & 99 & 99 \\
\hline & Glyphosate + imazethapyr + Soy Booster & $900 \mathrm{~g}$ ae $+45 \mathrm{~g}$ ai $+2 \mathrm{~L}$ & 100 & 100 \\
\hline \multirow[t]{2}{*}{ AMBEL } & Glyphosate + imazethapyr & $900 \mathrm{~g}$ ae $+45 \mathrm{~g}$ ai & 95 & 94 \\
\hline & Glyphosate + imazethapyr + Soy Booster & $900 \mathrm{~g}$ ae $+45 \mathrm{~g}$ ai $+2 \mathrm{~L}$ & 97 & 95 \\
\hline \multirow[t]{2}{*}{ CHEAL } & Glyphosate + imazethapyr & $900 \mathrm{~g}$ ae $+45 \mathrm{~g}$ ai & 99 & 98 \\
\hline & Glyphosate + imazethapyr + Soy Booster & $900 \mathrm{~g}$ ae $+45 \mathrm{~g}$ ai $+2 \mathrm{~L}$ & 98 & 98 \\
\hline \multirow[t]{3}{*}{ SETVI } & Glyphosate + imazethapyr & $900 \mathrm{~g}$ ae $+45 \mathrm{~g}$ ai & 100 & 100 \\
\hline & Glyphosate + imazethapyr + Soy Booster & $900 \mathrm{~g}$ ae $+45 \mathrm{~g}$ ai $+2 \mathrm{~L}$ & 100 & 100 \\
\hline & & & MT.hat ${ }^{-1}$ & \\
\hline \multirow[t]{3}{*}{ Yield } & Weedy control & & 2.51 & \\
\hline & Glyphosate + imazethapyr & $900 \mathrm{~g}$ ae $+45 \mathrm{~g}$ ai & 3.46 & \\
\hline & Glyphosate + imazethapyr + Soy Booster & $900 \mathrm{~g}$ ae $+45 \mathrm{~g}$ ai $+2 \mathrm{~L}$ & 3.48 & \\
\hline
\end{tabular}

Abbreviations: ABUTH, velvetleaf; AMASS, green or redroot pigweed; AMBEL, common ragweed; CHEAL, common lambsquarters; SETVI, green foxtail; WAT, weeks after herbicide application. Significance of contrasts comparing glyphosate + imazethapyr alone with glyphosate + imazethapyr + Soy Booster denoted by * for $\mathrm{P}<0.10$ and ** for $\mathrm{P}<0.05$ beside the means.

Table 8. Comparison of weed control 4 and 8 WAT, and yield for glyphosate/fomesafen alone vs glyphosate/fomesafen + Crop Booster in Roundup Ready soybean ${ }^{\mathrm{a}}$.

\begin{tabular}{|c|c|c|c|c|}
\hline \multirow{2}{*}{ Weed } & \multirow{2}{*}{ Treatment } & \multirow{2}{*}{ Rate $\left(\mathrm{ha}^{-1}\right)$} & \multicolumn{2}{|c|}{ Control (\%) } \\
\hline & & & $4 \mathrm{WAT}$ & 8 WAT \\
\hline \multirow[t]{2}{*}{ AMASS } & Glyphosate/fomesafen & $1200 \mathrm{~g}$ ai & 78 & 78 \\
\hline & Glyphosate/fomesafen + Crop Booster & $1200 \mathrm{~g}$ ai $+2 \mathrm{~L}$ & 76 & 77 \\
\hline \multirow[t]{2}{*}{ AMBEL } & Glyphosate/fomesafen & $1200 \mathrm{~g}$ ai & 85 & 83 \\
\hline & Glyphosate/fomesafen + Crop Booster & $1200 \mathrm{~g}$ ai $+2 \mathrm{~L}$ & 82 & 80 \\
\hline \multirow[t]{2}{*}{ CHEAL } & Glyphosate/fomesafen & $1200 \mathrm{~g}$ ai & 89 & 90 \\
\hline & Glyphosate/fomesafen + Crop Booster & $1200 \mathrm{~g}$ ai $+2 \mathrm{~L}$ & 93 & 93 \\
\hline \multirow[t]{2}{*}{ SETVI } & Glyphosate/fomesafen & $1200 \mathrm{~g}$ ai & 97 & 95 \\
\hline & Glyphosate/fomesafen + Crop Booster & $1200 \mathrm{~g}$ ai $+2 \mathrm{~L}$ & 98 & 97 \\
\hline \multirow[t]{3}{*}{ SINAR } & Glyphosate/fomesafen & $1200 \mathrm{~g}$ ai & 99 & 100 \\
\hline & Glyphosate/fomesafen + Crop Booster & $1200 \mathrm{~g} a \mathrm{a}+2 \mathrm{~L}$ & 99 & 100 \\
\hline & & & MT.ha ${ }^{-1}$ & \\
\hline \multirow[t]{3}{*}{ Yield } & Weedy control & & 2.24 & \\
\hline & Glyphosate/fomesafen & $1200 \mathrm{~g}$ ai & 3.76 & \\
\hline & Glyphosate/fomesafen + Crop Booster & $1200 \mathrm{~g} a \mathrm{a}+2 \mathrm{~L}$ & 3.78 & \\
\hline
\end{tabular}

Abbreviations: AMASS, green or redroot pigweed; AMBEL, common ragweed; CHEAL, common lambs quarters; SETVI, green foxtail; SINAR, wild mustard; WAT, weeks after herbicide application. Significance of contrasts comparing glyphosate/fomesafen alone with glyphosate/fomesafen + Crop Booster denoted by ${ }^{*}$ for $\mathrm{P}<0.10$ and ${ }^{\star *}$ for $\mathrm{P}$ $<0.05$ beside the means. 
Table 9. Comparison of weed control 4 and 8 WAT, and yield for glyphosate + quizalofop alone vs glyphosate + quizalofop + Crop Booster in Roundup Ready soybean ${ }^{\text {a }}$.

\begin{tabular}{|c|c|c|c|c|}
\hline \multirow{2}{*}{ Weed } & \multirow{2}{*}{ Treatment } & \multirow{2}{*}{ Rate $\left(\mathrm{ha}^{-1}\right)$} & \multicolumn{2}{|c|}{ Control (\%) } \\
\hline & & & 4 WAT & 8 WAT \\
\hline \multirow[t]{2}{*}{ AMASS } & Glyphosate + quizalofop & $900 \mathrm{~g}$ ae $+36 \mathrm{~g}$ ai & 94 & 94 \\
\hline & Glyphosate + quizalofop + Crop Booster & $900 \mathrm{~g}$ ae $+36 \mathrm{~g}$ ai $+2 \mathrm{~L}$ & 95 & 92 \\
\hline \multirow[t]{2}{*}{ AMBEL } & Glyphosate + quizalofop & $900 \mathrm{~g}$ ae $+36 \mathrm{~g}$ ai & 85 & 81 \\
\hline & Glyphosate + quizalofop + Crop Booster & $900 \mathrm{~g}$ ae $+36 \mathrm{~g} a \mathrm{i}+2 \mathrm{~L}$ & 85 & 84 \\
\hline \multirow[t]{2}{*}{ CHEAL } & Glyphosate + quizalofop & $900 \mathrm{~g}$ ae $+36 \mathrm{~g}$ ai & 93 & 90 \\
\hline & Glyphosate + quizalofop + Crop Booster & $900 \mathrm{~g}$ ae $+36 \mathrm{~g} a \mathrm{i}+2 \mathrm{~L}$ & 96 & 94 \\
\hline \multirow[t]{3}{*}{ SETVI } & Glyphosate + quizalofop & $900 \mathrm{~g}$ ae $+36 \mathrm{~g}$ ai & 99 & 99 \\
\hline & Glyphosate + quizalofop + Crop Booster & $900 \mathrm{~g}$ ae $+36 \mathrm{~g} a \mathrm{i}+2 \mathrm{~L}$ & 99 & 98 \\
\hline & & & MT.ha ${ }^{-1}$ & \\
\hline \multirow[t]{3}{*}{ Yield } & Weedy control & & 2.27 & \\
\hline & Glyphosate + quizalofop & $900 \mathrm{~g}$ ae $+36 \mathrm{~g}$ ai & 3.40 & \\
\hline & Glyphosate + quizalofop + Crop Booster & $900 \mathrm{~g}$ ae $+36 \mathrm{~g}$ ai $+2 \mathrm{~L}$ & 3.52 & \\
\hline
\end{tabular}

Abbreviations: AMASS, green or redroot pigweed; AMBEL, common ragweed; CHEAL, common lambsquarters; SETVI, green foxtail; WAT, weeks after herbicide application. Significance of contrasts comparing glyphosate + quizalofop alone with glyphosate + quizalofop + Crop Booster denoted by ${ }^{*}$ for $\mathrm{P}<0.10$ and ${ }^{*}$ for $\mathrm{P}<0.05$ beside the means.

Studies with the addition of Crop Booster to glyphosate (total of 12) were conducted at Exeter in 2003, 2004, 2014 and 2015 and at Ridgetown in 2002 (2 trials), 2003, 2004, 2005 ( 2 trials), 2014 and 2015 (Table 1). Studies with the addition of RR Soy Booster to glyphosate (total of 8) were conducted at Exeter in 2003 and 2004 and at Ridgetown in 2002 (2 trials), 2003, 2004 and 2005 (2 trials) (Table 2).

Studies with the addition of AX13-04-4 to glyphosate + chlorimuron (total of 6) were conducted at Exeter and Ridgetown in 2008-2010 (Table 3). Studies with the addition of Crop Booster to glyphosate + chlorimuron (total of 13) were conducted at Exeter in 2008, 2010, 2013, 2014 and 2015 (2 trials) and at Ridgetown in 2008, 2009, 2010, 2013, 2014 and 2015 (2 trials) (Table 4). Studies with the addition of RR Soy Booster to glyphosate + chlorimuron (total of 5) were conducted at Exeter in 2008 and 2010 and at Ridgetown in 2008, 2009 and 2010 (Table 5).

Studies with the addition of Crop Booster to glyphosate + imazethapyr (total of 9) were conducted at Exeter in 2008, 2010 and 2015 (2 trials) and at Ridgetown in 2008, 2009, 2010 and 2015 (2 trials) (Table 6). Studies with the addition of RR Soy Booster to glyphosate + imazethapyr (total of 5) were conducted at Exeter in 2008 and 2010 and at Ridgetown in 2008, 2009 and 2010 (Table 7).

Studies with the addition of Crop Booster to glyphosate + fomesafen (total of 6) were conducted at Exeter in 2011, 2012 and 2013 and at Ridgetown in 2012 (2 trials) and 2013 (Table 8). 
Studies with the addition of RR Soy Booster to glyphosate + quizalofop (total of 5) were conducted at Exeter in 2010 and 2011 and at Ridgetown in 2009, 2010 and 2011 (Table 9).

Field plots were $2 \mathrm{~m}$ wide and 8 or $10 \mathrm{~m}$ long. Soybean was seeded at 370,000 seeds $\mathrm{ha}^{-1}$ in rows that were spaced $0.75 \mathrm{~m}$ apart at a depth of $4 \mathrm{~cm}$ in May or early June of each year. Herbicide treatments were applied with a $\mathrm{CO}_{2}$ pressurized back-pack sprayer equipped with Hypro ULD120-02 nozzle tips (Hypro, New Brighton, MN) calibrated to deliver $200 \mathrm{~L} \cdot \mathrm{ha}^{-1}$ of water at $200 \mathrm{kPa}$. Herbicide applications were made with a $1.5 \mathrm{~m}$ boom with four nozzles spaced $50 \mathrm{~cm}$ apart.

Crop injury 1 and 4 weeks after herbicide treatment (WAT) and weed control (4 and $8 \mathrm{WAT}$ ) were visually estimated on a scale of 0 (no injury/control) to $100 \%$ (complete plant death/complete weed control). Soybean was harvested from each plot with a small plot combine, weight and moisture were recorded, and yields were adjusted to $13 \%$ moisture.

Data were analyzed as an RCBD using PROC MIXED in SAS 9.4. Herbicide treatment was considered a fixed effect, while environment (year-location combinations), the interaction between environment and herbicide treatment, and replicate nested within environment were considered random effects. Significance of the fixed effect was tested using F-test and random effects were tested using a Z-test of the variance estimate. The UNIVARIATE procedure was used to test data for normality and homogeneity of variance. The untreated check was excluded from the analysis for weed control data. Data were arcsine square root transformed when necessary to satisfy the assumptions of the variance analyses. Treatment comparisons were made using contrasts. Data compared on the transformed scale were converted back to the original scale for presentation of results.

\section{Results and Discussion}

Prominent weed species in this study included velvetleaf (Abutilon the ophrasti Medic.; ABUTH), redroot pigweed (Amaranthus retroflexus L.; AMARE), common ragweed (Ambrosia artemisiifolia L.; AMBEL), common lambsquarters (Chenopdium album L.; CHEAL); green foxtail (Setaria viridis L.; SETVI) and annual grasses. Weed control for each species were analyzed only when they existed in at least $50 \%$ of field plots (Tables 1-9).

\subsection{Glyphosate}

There was no injury in soybean with the addition of Crop Booster or RR Soy Booster to glyphosate (data not shown). Weed control with glyphosate plus Crop Booster or RR Soy Booster ranged from $80 \%$ to $99 \%$ at $4 \mathrm{WAT}$ and $79 \%$ to $98 \%$ at $8 \mathrm{WAT}$ depending on weed species (Table 1, Table 2). The addition of Crop Booster or RR Soy Booster to glyphosate did not impact the control of pigweed species, common ragweed, common lambsquarters, wild mustard, and green foxtail at 4 WAT or 8 WAT (Table 1).

The addition of Crop Booster or RR Soy Booster to glyphosate resulted in a numeric 
increase soybean yield of $0.06-0.07 \mathrm{MT} \cdot \mathrm{ha}^{-1}$ compared to glyphosate applied alone but the differences were not statistically significant (Table 1, Table 2). Glyphosate alone or in combination with Crop Booster or RR Soy Booster increased soybean yield more than $30 \%$ compared to the weedy control. In other studies, biostimulants such as $\mathrm{Hu}$ mates were found to increase yield of vegetable crops. Other studies have shown increases in corn yield with seaweed biostimulants [9]. Al-Majathoub [11] studying four different biostimulants (Vigro, Biomin, Humiplus and Humacare) found greater than $8 \%$ increase in wheat yield with some biostimulants.

\subsection{Chlorimuron}

There was minimal soybean injury (5\% or less) with glyphosate + chlorimuron and glyphosate + chlorimuron in combination with AX13-04-4, Crop Booster or RR Soy Booster at 1 WAT (data not shown). All injury ratings were zero at 4 WAT (data not shown). Weed control with glyphosate + chlorimuron and glyphosate + chlorimuron + AX13-04-4 ranged from $96 \%$ to $100 \%$ (Table 3); weed control with glyphosate + chlorimuron and glyphosate + chlorimuron + Crop Booster ranged from 93\% to 100\% (Table 4); and weed control with glyphosate + chlorimuron and glyphosate + chlorimuron + RR Soy Booster ranged from $83 \%$ to $100 \%$ (Table 5). The addition of AX13-04-4, Crop Booster or RR Soy Booster to glyphosate + chlorimuron did not cause any significant differences on the control of weed species evaluated except for control of common lambs quarters which was increased slightly at 8 WAT with the addition of Crop Booster (Tables 3-5).

The addition of AX13-04-4, Crop Booster or RR Soy Booster to glyphosate + chlorimuron resulted in a small numeric increase in soybean yield of $0.05,0.01$ and 0.07 MT.ha ${ }^{-1}$, respectively compared to glyphosate + chlorimuron but the differences were not statistically significant (Tables 3-5). Glyphosate + chlorimuron alone or in combination with AX13-04-4, Crop Booster, and RR SoyBooster increased soybean yield more than $32 \%, 42 \%$, and $35 \%$ compared to the weedy control, respectively (Tables 3-5).

\subsection{Imazethapyr}

There was minimal injury (4\% or less) with glyphosate + imazethapyr alone or in combination with Crop Booster or RR Soy Booster at 1 WAT (data not shown). All injury ratings were zero by 4 WAT (data not shown). Weed control with glyphosate + imazethapyr and glyphosate + imazethapyr + Crop Booster ranged from 96\% to 100\% (Table 6) and with glyphosate + imazethapyr and glyphosate + imazethapyr + RR Soy Booster ranged from $85 \%$ to $100 \%$ (Table 7). The addition of Crop Booster and RR Soy Booster to glyphosate + imazethapyr did not cause any significant differences on the control of weed species evaluated except for control of common ragweed which was increased slightly at 4 WAT with the addition of RR Soy Booster (Table 6, Table 7).

The addition of Crop Booster and RR Soy Booster to glyphosate + imazethapyr did not impact soybean yield (Table 6, Table 7). Glyphosate + imazethapyr alone or in 
combination with Crop Booster and RR Soy Booster increased soybean yield more than $33 \%$ and $38 \%$ compared to the weedy control, respectively (Table 6 , Table 7 ).

\subsection{Fomesafen}

There was $6 \%$ soybean injury with glyphosate + fomesafen and glyphosate + fomesafen + Crop Booster (data not shown). All injury was zero by 4 WAT (data not shown). Control of pigweed species, common ragweed, common lambsquarters, green foxtail and wild mustard in plots treated with glyphosate + fomesafen and glyphosate + fomesafen + Crop Booster ranged from $76 \%$ to $99 \%$ at 4 WAT and $77 \%$ to $100 \%$ at 8 WAT (Table 8). The addition of Crop Booster to glyphosate + fomesafen did not cause any significant differences on the control of weed species evaluated except for the control of common lambsquarters which was increased as much as $4 \%$ at 4 and 8 WAT and green foxtail which was increased $2 \%$ at 8 WAT with the addition of Crop Booster (Table 8).

The addition of Crop Booster to glyphosate + fomesafen did not cause a significant increase in yield of RR soybean (Table 8). Glyphosate + fomesafen alone or in combination with Crop Booster increased soybean yield more than $68 \%$ compared to the weedy control (Table 8).

\subsection{Quizalofop}

There was less than $2 \%$ soybean injury with glyphosate + quizalofop alone or in combination with Crop Booster at 1 WAT. The injury observed was transient with no injury at 4 WAT (data not shown). Control of pigweed species, common ragweed, common lambsquarters, and green foxtail in plots treated with glyphosate + quizalofop and glyphosate + quizalofop + Crop Booster ranged from $85 \%$ to $99 \%$ at 4 WAT and $81 \%$ to 99\% at 8 WAT (Table 9). The addition of Crop Booster to glyphosate + quizalofop did not cause any significant differences on the control of weed species evaluated except for the control of common lambsquarters which was increased $4 \%$ at 8 WAT with the addition of Crop Booster (Table 9).

The addition of Crop Booster to glyphosate + quizalofop resulted in a small numeric increase soybean yield of $0.12 \mathrm{MT} \cdot \mathrm{ha}^{-1}$, but the difference was not statistically signi-ficant (Table 9). Glyphosate + quizalofop alone or in combination with Crop Booster increased soybean yield more than $50 \%$ compared to the weedy check (Table 9).

\section{Conclusion}

There was no increase in soybean injury with the addition of the biostimulants evaluated when added to glyphosate, glyphosate + chlorimuron, glyphosate + imazethapyr, glyphosate + fomesafen, or glyphosate + quizalofop. Also, the addition of biostimulants to glyphosate, glyphosate + chlorimuron, glyphosate + imazethapyr, glyphosate + fomesafen and glyphosate + quizalofop did not affect weed control except for a slight increase in the control of common ragweed with the addition of RR Soy Booster to glyphosate + imazethapyr, a slight increase in the control of common lambsquarters with the addition of Crop Booster to glyphosate + fomesafen, a slight increase in the control 
of green foxtail with the addition of Crop Booster to glyphosate + fomesafen and a slight increase in the control of common lambsquarters with the addition of Crop Booster to glyphosate plus chlorimuron or fomesafen or quizalofop. There was generally a small numeric increase in soybean yield with the addition of biostimulants to the herbicides evaluated, but this increase in yield was not statistically significant at the $\mathrm{p}<$ 0.05 level.

\section{Acknowledgements}

The authors would like to acknowledge Todd Cowan and Lynette Brown for their expertise and technical assistance in these studies.

\section{References}

[1] Agriculture and Agri-Food Canada [AAFC] (2015) Weekly Price Summary. http://www.agr.gc.ca/eng/industry-markets-and-trade/statistics-and-market-information/b y-product-sector/crops/crops-market-information-canadian-industry/weekly-price-summa ry/?id=1378745200250

[2] Kulasekera, K. (2015) Soybean: Area and Production, by County, Ontario Ministry of Agriculture and Rural Affairs.

http://www.omafra.gov.on.ca/english/stats/crops/estimate_new.htm\#metric

[3] European Biostimulant Industry Council, EBIC (2012) http://www.biostimulants.eu/website

[4] Shekhar Sharma, H.S., Fleming, C., Selby, C., Rao, J.R. and Martin, T. (2014) Plant Biostimulants: A Review on the Processing of Macroalgae and Use of Extracts for Crop Management to Reduce Abiotic and Biotic Stresses. Applied Phycology, 26, 465-490. http://dx.doi.org/10.1007/s10811-013-0101-9

[5] Zhang, X. (1997) Influence of Plant Growth Regulators on Turfgrassgrowth, Antioxidant Status, and Drought Tolerance. Ph.D. Thesis, Virginia Polytechnic Institute and State University, Blacksburg.

[6] Khan, W., Rayorath, U.P., Subramanian, S., Jithesh, M.N., Rayorath, P., Hodges, D.M., Critchley, A.T., Craigie, J.S., Norrie, J. and Prithiviraj, B. (2009) Seaweed Extracts as Biostimulants of Plant Growth and Development. Journal of Plant Growth Regulation, 28, 386399. http://dx.doi.org/10.1007/s00344-009-9103-x

[7] Sanderson, K.J., Jameson, P.E. and Zabkiewicz, J.A. (1987) Auxin in a Seaweed Extract: Identification and Quantitation of Indole-3-Acetic Acid by Gas Chromatography-Mass Spectrometry. Journal of Plant Physiology, 129, 363-367. http://dx.doi.org/10.1016/S0176-1617(87)80093-7

[8] Hanson, K.R. (1988) Plant Nutritional Activators Increase Vegetable Yield. Citrus and Vegetable Magazine, 7, 10-12.

[9] Chapman, V.J. and Chapman, D.J. (1980) Seaweeds and Their Uses. 3rd Edition, Chapman and Hall, Ltd., London. http://dx.doi.org/10.1007/978-94-009-5806-7

[10] Redmond, S. (2009) Crop Growth Promoting Products on Soys/Corn/Wheat. Crop Advances. Field Crop Reports, 1-2.http://www.ontariosoilcrop.org/docs /v6gen3.pdf

[11] Al Majathoub, M. (2004) Effect of Biostimulants on Production of Wheat (Triticum aestivum L.). In: Cantero-Martínez, C. and Gabiña, D., Eds., Mediterranean Rainfed Agriculture: Strategies for Sustainability, CIHEAM, Zaragoza, 147-150.

[12] Axter Agrosciences Inc. (2015) Fact Sheet-Biostimulant: Crop Booster. 
http://www.axter.ca/wp-content/uploads/2015/04/Crop-Booster_Fiche-Produit-ANG_Mar ch-2015.pdf

[13] Axter Agrosciences Inc. (2015) Label: Crop Booster.

http://www.axter.ca/wp-content/uploads/2015/04/Crop-Booster_Etiquette-ANG_March-20 15vf.pdf

[14] Axter Agrosciences Inc. (2015) Label: Soy Booster. http://www.axter.ca/wp-content/uploads/2015/04/RR-Soy-Booster_Etiquette-ANG_Mars-2 015.pdf

\section{Abbreviations}

Abbreviations: ABUTH, velvetleaf;

AMASS, green or redroot pigweed;

AMBEL, common ragweed;

CHEAL, common lambsquarters;

SOLPT, Eastern black nightshade;

SINAR, wild mustard;

SETVI, green foxtail;

WAT, weeks after herbicide treatment.

Submit or recommend next manuscript to SCIRP and we will provide best service for you:

Accepting pre-submission inquiries through Email, Facebook, LinkedIn, Twitter, etc. A wide selection of journals (inclusive of 9 subjects, more than 200 journals)

Providing 24-hour high-quality service

User-friendly online submission system

Fair and swift peer-review system

Efficient typesetting and proofreading procedure

Display of the result of downloads and visits, as well as the number of cited articles Maximum dissemination of your research work

Submit your manuscript at: http://papersubmission.scirp.org/ 